\title{
Implementation of Pancasila Value for Generation Z in Technology Development
}

\author{
Evelyn Angelita Pinondang Manurung ${ }^{1}$ \& Maria Osmunda Eawea Monny ${ }^{2}$ \\ Program Studi Teknik Informatika, STMIK STIKOM Indonesia \\ Email: evelynangelita@stiki-indonesia.ac.id¹ \& maria.monny@stiki-indonesia.ac.id²
}

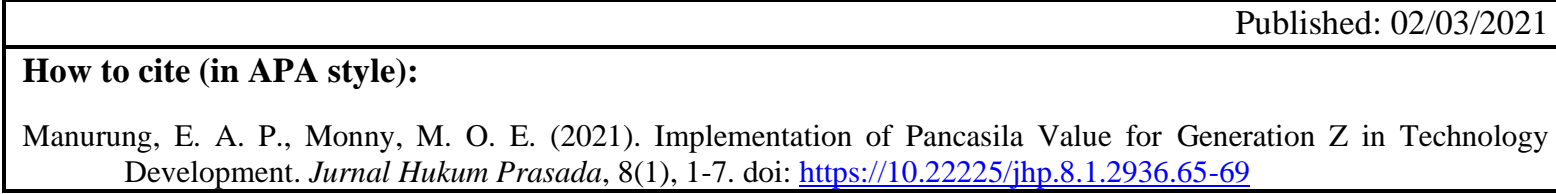

\begin{abstract}
As the ideology of Indonesia, the existence of Pancasila is not without any challenges. In the development of science and technology, the existence of Pancasila is full of struggles. One of the challenges is the rapid social development that have happened nowadays has brought some changes in social activities. These social changes are marked by the development of the generation based on the needs for science and technology. Generation Z nowadays is known as the most active in their activities that depends on the technology devices and for this reasons generation $Z$ needs strong guidelines in utilizing it. The implementation Pancasila value for Generation Z must be in accordance with the needs of Generation $Z$ that are vulnerable for the ethics and morality. The knowledge of Pancasila value with dynamic ways for Generation $Z$ is important so the moral value in Pancasila can be reflected in the personality of Generation $Z$. The research aims to implement the value of Pancasila that is important for the development of generation $Z$ in the rapid progress of technology nowadays. This research used qualitative method. The implementation of moral science and characters based on Pancasila for Generation Z should be dynamics in accordance with the development of technological era. The implementation of Pancasila value based on their needs and characters of Generation $Z$ is an anticipative way so the value of believe in God, humanity, unity, democracy and social justice still exist and create young generation that have the moral value of Pancasila.
\end{abstract}

Keyword: Generation Z; Pancasila Value; Technology

\section{INTRODUCTION}

Pancasila as nation's ideology has the important roles in facing the global challenges that lead to social changes nowadays. Pancasila as a guideline will be always needed by Indonesia mostly young generation in facing the development of people's activities. Pancasila as nation's ideology is not only about set of rules or regulations, however Pancasila guides the people of Indonesia to behave and have the characters in accordance with the value of Pancasila. As nation's ideology, Pancasila did not form at once and it was not created by person just like the ideology in other countries in the world. However, Pancasila was formed through a long process in the history of Indonesia. In its process, Pancasila was formulated by the founding fathers of the country by relying on the fundamental values of Indonesia and it was synthesized by the global ideas of the world (Kaelan, 2014).

The teaching of pancasila for young generations must be focused on how to build up their understanding and appreciation about the ideology of Indonesia. This is meant that the teachng of Pancasila is expected can become the spirit in forming the identitiy of young generations to develop their proesionalism in accordance with their field of study. Besides, referring to the regulations in article 2 Act Number 12 of 2012, higher educational system in Indonesia must be guided by Pancasila. This means, in its implementation, higher education 
in Indonesia must keep on developing the value of Pancasila in all its policies and conducting the subject Pancasila preciously and responsible (General Director and Students Affairs Education Ministry, 2016).

For Indonesia as a country, the essential obstacles nowadays is the rapid development of social together with the development of sciences and technology that have taken important roles in human daily basis activities. Generation $Z$ is the easiest generation who can have an occupation or those students who are still studying at the colleges. Generation $Z$ nowadays are representative of social changes that depend on the development of technology's devices. Nowadays, Generation Z has taken control on the changing and social development in a broader scope of people. Generation $Z$ has taken control on social activities by using technology's devices instantly and fast.

In line with the development of sciences and technology from generations to generations that have the impact on human's life, there is also a social changing in society. In the middle of technology's development nowadays, social changes on young generations or the productive ages in the contrary, has the decrease of moral mostly on etiquette and moral that are almost taken aside. The characters or spirit of Pancasila that was upheld by the people of Indonesia for long period of time have been taken aside due to the development of technology. Social development has shown that Generation $Z$ do not pay attention to the norms that exist in the society or in other words, most of Generation Z misbehave. The value of Pancasila is not shown from the characters of Generation Z. This is challenge for the teachers or educators to rebuild the character or spirit of Pancasila in the heart and soul of Generation Z. Knowing and understanding fully the character of Generation Z, learning and following their perspective or even using technology's devices that are really familiar with their activities is an alternative in implementing the value of Pancasila for Generation Z in the middle of technology's development.

\section{METHOD}

The approach for the problem in this research is seen from analysis interest and its discussion by using qualitative research method. This research used as a scientific method that is mostly used as a guideline by a group of research in social studies and educations. The nature of this research is observing the people in their society on how they interact with each other, try to understand their language and interpretation about their environment, be close to the and do interaction with them that have the correlation with the focus of the research with the purpose to understand, investigate their perspective and experiences in order to get the information or data (Iskandar, 2009). Through this method, the researcher observed the interaction, activities and environment that have the impacts on the objects those are groups of people which is called Generation Z.

\section{RESULT AND DISCUSSION}

The big challenge of Indonesia as a country recently is the rapid progress of social development in global scope that cannot be facing only by partition or physical security between countries or nations. The development of society all over the world is marked by the growth and development of young generations from time to time with different characters and needs (Mahfud, 2018).

Furthermore, here are the understanding about generation and its group. According to Kupperschmidt (2000) in (Putra, 2016) generation is a group of people that have the similarity of date of birth, age, locations, and historical experiences or incidentals in the individuals that have significant impacts in their phase of growth. To summarize, it can be said that generation is a group of individual that have experienced the same incidents at the same periods of time. The basic understanding on the grouping of generation is there is a premise that generation is a group of individual that was influenced by the historical incidents cultural phenomenon that happened and experienced in their stages of life, where those incidents and phenomenon has caused a collective remembrance that have impacts on their life. So, the incidents in 
history, social and cultural effects together with other factors have influenced the formation of individual, norms and characters (Caspi, Roberts, \& Shiner, 2005).

In the literature about the differences of generations, it is used a general criterionand can be accepted in all regions, in this case the criteria that used are year of birth and the incidents that happened globally (Twenge, 2006). According to (Howe \& Strauss, 2000), there are three atributs that are clearer to identify generation compares to year of birth, those attributes are as follows :

1. Percieved membership: individual perceptions on a group where there are parts of it, mostly for teenager to adolescent.

2. Common belief and behaviors: the behaviors towards family, carrier, personal life, politics, religions, and other choices that have been taken due to occupations/jobs, marriage, children, health and crime.

3. Common location in history: the changes on point of view of politics, historical incidents, for examples: wars, natural disasters, which happened during the teenager and adolescent periods.

The differences of characters which are the most significant between Generation $X, Y$ and $Z$ is in forms of the mastery of information and technology. For Generation Z, information and technology are parts of their life because they were born where the access to internet has become their basic needs, so it has the impacts on their way of thinking. In this year, the average in educational sectors shows that generations that are still studying at the college level is Generation Z. Generation Z is mostly fond of adventures and interested to try new things by using technology. They tend to be overconfidence, brave enough to express their opinions directly or through social media. This generation has grown up together with the emerge of many new innovations in communications technology and features short messages from Whatsapp, Line, Twitter, Instagram and other forms of written communication. This form of written communication in social media is considered more comfortable and appropriate for generation Z. They are able to apply all activities in a time (multi-tasking) for examples: active at social media using cellphone, browsing using gadget and listening to music using headset. Anything that they do is mostly something to do with social media. Since their childhood, this generation has known technology and familiar with sophisticated gadget that unconsciously has the impact on their personality and characters.

Pancasila also has the characteristic as an open ideology which means the value of Pancasila can be developed in accordance with the development of this era in living the life as a nation. This dynamics character is needed in order to maintain national security in the middle of modern development (Maharani \& et al., 2019) .In this case, Pancasila is able to adjust itself in this era development. An open ideology is an ideology that able to adjust with the development of an era and dynamics in its nature. In other words, the value of Pancasila can be developed in accordance with the life of Indonesia as a nation and the demands of this era development. (kompas.com accessed 25 July 2020). Pancasila as an ideology has mirrored its open minded or point of view that is able to accept all kinds of changes. This means, Pancasila is able to adjust itself with all changes that happened in Indonesia and with its open nature, Pancasila is able to be understood by every generation of this nation mostly young generation. For Indonesia as a nation, this open minded is based on the varied of society which is a reflection of a reality that this nation consists of various ethnics with its richness on it. The varied of society law in Indonesia must be guarded and given the space to be developed based on society dynamics in accordance with and controlled of national law that has the highest poit whichis constitution (Ropii, 2017).

The rapid progress in sciences, technology and global communication facility that become more modern, has made this world spinning rapidly. In accordance with it, social interaction among the people is lessened because people depend their life on technology media to help them in doing their activities and daily works. The role of Pancasila is to give the orientation in the future has required Indonesia as a nation to realize the real situation now 
(Abdulkarim, 2008). This means, national development does not depend on internal factors. It can be affected by foreign factors. in order to face this situation and condition, ideology of Pancasila is considered need to be understood as an open ideology. This is due to the facts that young generation of this nation is easily affected by a point of view/perspective or even a doctrine of foreign countries.

Generation Z now depends almost all of their information needs on the sophisticated technology devices that is multipurpose for examples for food, transportations, and services in a hand with gadget. It can be said that the role of human in doing the occupations/jobs is lessen and the interaction among people becomes rare. Due to that reasons, Generation Z is needed to be given the value of Pancasila those are patriotism and nation's identity. Lots of crime/misled of moral and etiquette even law happened due to the decrease of the value of Pancasila in this digital technology era. This situation has brought some concerns for the teachers and educators that have the correlation with the teaching of moral science and characters. Pancasila as the guideline for Indonesia as a nation is form also a form of guideline for the characters of its citizens mostly young generations. In this development of digital technology era, the attitude of Generation $Z$ din their social life has shown the misled from the moral and etiquette and even the love for the country too. Generation Z seems like busy with themselves. No wonders if some people said that generation $Z$ as anti-social.

The older generation (before Generation Z) mostly teachers and educators has important roles to prepare all ways and efforts and make it possible that the ideology of Pancasila that have been there in the history can be part of life for Generation Z in order to build human resources that have humanity values. The teachers/educators and parents must try their best to adjust themselves with the point of view ad characters of Generation Z so the value of Believe in God, humanity, Unity, Democracy and Social Justice will become parts of generation $Z$ and will be applied in their daily life.

The use of various learning platform for every level of study, (as long as it is about the actualization of Pancasila) is mostly dominated by one learning platform. Most of the time, formal education institutions do not provide other form of platform. In other words, young generation must look/search for other platform. In this searching, this young generation will be contended with what they have been searching for but not all of those forms can build toards the actualization of Pancasila. Platform is understood as tools, ways, and targets. In this way, various platforms can take the experiences of a figure, activator, and examples of practices not in written forms. The experiences will give the incentive for young generation to develop their roles themselves (Latif, 2018). Due to that reasons, the platforms of learning Pancasila for Generation $\mathrm{Z}$ is not rigid and monotone. The influence of technology development nowadays has opened wider our knowledge that educational platform for learning must be adjusted with the development of young generation. Pancasila must be taken as a benchmark for the characters for young generation mostly for Generation Z in living their social life, as citizen of a nation and country. Considering the lifestyle and characters of generation $Z$ nowadays, Pancasila must not be taught in a formal and rigid but must be adjusted with the characters of Generation Z.

Generation $Z$ which is known as i-Generation depends almost all of their needs on interconnection networking (internet). This is also included for information and knowledge. For this reasons, building up moral and characters of Generation Z must be based on the spirit of Pancasila and adjusted with the conditions of their characters nowadays. The implementation of the value of Pancasila with old fashion teaching method is not relevant to the conditions of Generation Z. Generation Z is not used to read a conventional book or having group studying with their classmates. The implementation of moral science and characters or Generation Z must be based on Pancasila in accordance with the changing of this era and technology development. With the delivery of knowledge and it methods by using technology devices is expected to be understood better by Generation Z. In its nature, the message of this knowledge will be easily understood by them. It is expected that Generation Z ca implement the values of Pancasila in their daily life. 


\section{CONCLUSION}

The development of this era is marked by the development of generations too. In the gropu of society, generation $Z$ is mostly seen doing their daily activities mostly in mastery of and using of informatics system and technology. For Generation Z, information and technology have become parts of their life and has influences their way of thinking and characters.

Pancasila as a nation ideology has important roles in facing global challenges that has led to social changes nowadays. Pancasila as the guideline is always be needed by Indonesia as a nation in facing this development situation in all fields of activities in the society. The implementations of the value of Pancasila become important for young generation mostly Generation Z. Generation Z is mostly affected by technology development or even almost all their activities are depended on digital devices. The building up of moral and characters of Generation Z that guided by the spirit of Pancasila supposedly adjusted with the condition and characters of Generation Z nowadays. The implementation of the value of Pancasila by using conventional teaching methods is considered not relevant to the condition of Generation Z. The implementation of the value of Pancasila for Generation $Z$ is supposedly adjusted with the changes of this era and technology development. With appropriate ways of teaching, the knowledge and its method can be transformed by using technology devices that mostly used by Generation Z.

The existence of Generation $Z$ in Indonesia has strengthened the point of view and analysis that knowledge has its dynamics roles as the ideology of Pancasila that has its open nature that can be developed dynamically. It is important for the teachers and educators that has the directs roles to the teaching of Pancasila to prepare an anticipative way so the ideology of Pancasila that has the values of Belive in God, Humanity, Unity, Democracy and Sosial Justice can take its important roles for Indonesia, the developing of human resources, and building up of every generation with the good moral value and based on Pancasila.

\section{REFERENCES}

Abdulkarim, A. (2008). Pendidikan Kewarganegaraan. Bandung: Grafindo Media Pratama.

Caspi, A., Roberts, B. W., \& Shiner, R. L. (2005). Personality development: Stability and Change. Annual Review of Psychology, 56.

Howe, N., \& Strauss, W. (2000). Millennials rising: The next great generation. New York: Vintage.

Iskandar. (2009). Metode Penelitian Kualitatif. Jakarta: Gaung Persada.

Kaelan. (2014). Pendidikan Pancasila. Yogyakarta: Paradigma.

Latif, Y. (2018). Identitas Keindonesiaan Dan Aktualisasi Pancasila Bagi Generasi Milenial Di Era Digital. Jurnal Kajian LEMHANNAS RI, 33.

Maharani, S., \& et al. (2019). Indeks Ketahanan Ideologi Pancasila. Jurnal Ketahanan Nasional, 25(2).

Mahfud, M. (2018). Mengokohkan Ideologi Pancasila Menyongsong Generasi Z-Alpha. Universitas Soegiyopranoto.

Putra, Y. S. (2016). Theoritical Review: Teori Perbedaan Generasi. Jurnal Among Makarti, 9(18).

Ropii, I. (2017). Penghormatan Pluralitas Hukum Masyarakat Dalam Bingkai Hukum Nasional Sebagai Sarana Meneguhkan Integrasi Bangsa. Jurnal Hukum Prasada, 4(1).

Twenge, J. M. (2006). Generation Me: Why Today's Young Americans Are More Confident, Assertive, Entitled and More Miserable Than Ever Before. New York: Free Press.

Direktorat Jendral Pembelajaran dan Kemahasiswaan KEMRISTEKDIKTI. (2016). Pendidikan Pancasila Untuk Perguruan Tinggi. Cetakan 1.

Undang-Undang Nomor 12 Tahun 2012 Tentang Pendidikan Tinggi

Kompas.com, $\quad$ https://www.kompas.com/skola/read/2020/03/11/170000469/pancasila-sebagaiideologi-terbuka?page=all, diakses 25 Juli 2020. 